\title{
Seasonal and Annual Changes of the Regional Tropical Belt in GPS-RO Measurements and Reanalysis Datasets $\mathscr{}$
}

\author{
LAN LUAN AND PAUl W. STATEN \\ Department of Earth and Atmospheric Sciences, Indiana University Bloomington, Bloomington, Indiana \\ CHI O. AO \\ Jet Propulsion Laboratory, California Institute of Technology, Pasadena, California \\ QIANG FU \\ Department of Atmospheric Sciences, University of Washington, Seattle, Washington
}

(Manuscript received 9 September 2019, in final form 12 January 2020)

\begin{abstract}
The width of the tropical belt has been analyzed with a variety of metrics, often based on zonal-mean data from reanalyses. However, constraining the global and regional tropical width requires both a global spatialresolving observational dataset and an appropriate metric to take advantage of such data. The tropical tropopause break is arguably such a metric. This study aims to evaluate the performance of different reanalyses and metrics with a focus on depicting regional tropical belt width. We choose four distinct tropopause-break metrics derived from global positioning system radio occultation (GPS-RO) satellite data and four modern reanalyses (ERA-Interim, MERRA-2, JRA-55, and CFSR). We show that reanalyses generally reproduce the regional tropical tropopause break to within $10^{\circ}$ of that in GPS-RO data-but that the tropical width is somewhat sensitive (within $4^{\circ}$ ) to how data are averaged zonally, moderately sensitive (within $10^{\circ}$ ) to the dataset resolution, and more sensitive $\left(20^{\circ}\right.$ over the Northern Hemisphere Atlantic Ocean during JuneAugust) to the choice of metric. Reanalyses capture the poleward displacement of the tropical tropopause break over land and equatorward displacement over ocean during summertime, and the reverse during the wintertime. Reanalysis-based tropopause breaks are also generally well correlated with those from GPS-RO, although CFSR reproduces 14-yr trends much more closely than others (including ERA-Interim). However, it is hard to say which dataset is the best match of GPS-RO. We further find that the tropical tropopause break is representative of the subtropical jet latitude and the Northern Hemisphere edge of the Hadley circulation in terms of year-to-year variations.
\end{abstract}

\section{Introduction}

In recent decades, the tropics have been observed to widen, with a possible (and expected) role of greenhouse gas concentration increases (Fu et al. 2006; Hudson et al. 2006; Seidel and Randel 2007; $\mathrm{Hu}$ and Fu 2007; Seidel et al. 2008; Johanson and Fu 2009; Davis and Rosenlof 2012; Davis and Birner 2013, 2017; Lucas and Nguyen 2015; Davis et al. 2018; Staten et al. 2018;

Supplemental information related to this paper is available at the Journals Online website: https://doi.org/10.1175/JCLI-D-190671.s1.

Corresponding author: Lan Luan, lanluan@iu.edu
Waugh et al. 2018; Chemke and Polvani 2019a; Grise et al. 2019; Watt-Meyer et al. 2019). A widening of the tropical belt is anticipated to have myriad surface impacts over land and ocean at the local level, with potentially serious societal implications (Held and Hou 1980; Held and Soden 2000; Lu et al. 2007, 2008; Davis and Rosenlof 2012; Feng and Fu 2013; Staten et al. 2014; Davis and Birner 2016; Chemke and Polvani 2019b). But connecting tropical widening with local impacts requires metrics for the regional width of the tropics.

The regional tropical edge is difficult to define, however. The differences noted between metrics at the global scale are at times exacerbated on the regional scale, where many metrics are poorly defined. This is 
either because the marker in question may not occur at every longitude (e.g., with threshold metrics for outgoing longwave radiation) (Waugh et al. 2018) or because the underlying observational data are too sparse (e.g., as with wind or pressure data) (L'Heureux et al. 2013). Observed estimates of tropical width, then, often focus on land where station data are most abundant (Xian and Homeyer 2019). Data assimilation can, of course, be used to fill in the gaps between stations, but reanalysis-derived tropical width metrics [such as the Hadley cell (HC)] may suffer from spurious trends in reanalyses (Chemke and Polvani 2019b) and are difficult to validate with observations; reanalyses are both useful and difficult to validate for the same reason (Waliser et al. 1999). Satellite data span the globe, but not all metrics can be calculated from current remotely sensed datasets.

The tropical tropopause break (TTB) - the latitude at which the higher tropical tropopause gives way to the lower subtropical tropopause-is a globally observable metric relevant to tropical width. The TTB can be defined at all longitudes and is readily derived from globally gridded air temperatures from global positioning system radio occultation (GPS-RO) data (Anthes et al. 2008; Staten and Reichler 2008). These data confirm the validity of the reanalyses-derived tropical width in the zonal mean (Birner 2010; Ao and Hajj 2013; Davis and Birner 2013), and from region to region in the seasonal and annual mean (Mathew and Kumar 2018, hereinafter MK18). However, the relationship between the TTB and more conventional tropical width metrics (such as the $\mathrm{HC}$ edge) vary-from a weak correlation (0.1) in model data to a moderate correlation (0.6) in reanalyses (Waugh et al.2018). This casts some doubts on the utility of the TTB as a metric of tropical width that is relevant to surface climate. On the other hand, the TTB seems to vary with the subtropical jet (STJ) latitude (Davis and Birner 2017; Waugh et al. 2018), which likewise is expected to shift poleward (Kushner et al. 2001; Yin 2005; Miller et al. 2006; Fu and Lin 2011; Swart and Fyfe 2012; Staten et al. 2012, 2014; Barnes and Polvani 2013; Ceppi and Hartmann 2013; Ceppi et al. 2014, 2018; Simpson et al. 2014; Staten and Reichler 2014), even if not at the same rate as lower tropospheric metrics (Davis and Birner 2017; Waugh et al. 2018; Menzel et al. 2019). However, previous studies primarily discuss the above advantages and limitations of the zonal-mean TTB with the exception of the agreement between metrics shown in MK18.

This study examines the TTB from monthly GPS-RO data and reanalyses to 1 ) document the regional, seasonal structure of the TTB, 2) validate the TTB as depicted in reanalyses, and 3) determine which of the differences in previous studies can be attributed to the data source, to the data resolution, or to the TTB metric employed. We confirm the seasonal cycle in MK18, including the strong variance between metrics over the east Pacific during austral summer in Southern Hemisphere ( $\mathrm{SH})$, and a strong poleward shift of the tropical belt over the land during summer. In our study, differences between TTBs from GPS-RO and reanalyses are generally less than $10^{\circ}$ lat, and often less than $1^{\circ}$ lat, particularly when the reanalyses are degraded to match the resolution of the gridded GPS-RO dataset. Indeed, we find that differences in metric matter much more than the choice of dataset (at least for modern reanalyses) and resolution, in both the zonal-mean and regional level climatology. In particular, during the summer seasons over the ocean, the TTB can be better described as a tropopause transition zone, with the transition taking place over as much as $30^{\circ}$ lat, making point-wise metrics problematic in these regions and in the zonal mean. In addition, reanalyses more closely match tropical belt seasonality and structure from GPS-RO in the regional scale than the annual variability in the zonal mean. For the zonal tropical belt widening trend, CFSR is closer to GPS-RO than other reanalyses.

The remainder of this paper is laid out as follows. In section 2, we describe the GPS-RO and reanalysis data and the tropical width metrics used. In section 3 , we document the seasonality of regional TTB (section 3a), validate TTBs from reanalyses (section $3 b$ ), and analyze the sensitivity of the TTB to the choice of resolution, reanalysis, and metric (section $3 \mathrm{c}$ ). We summarize our results in section 4 .

\section{Data and methods}

\section{a. GPS-RO data}

The GPS-RO technique, as applied to Earth's atmosphere, was described by Kursinski et al. (1997). The temperature and geopotential height data (available from https://genesis.jpl.nasa.gov) used in our study consist of GPS-RO from the Challenging Minisatellite Payload (CHAMP) mission (March 2002-October 2008), with an average of 3000 soundings per month and the Constellation Observing System for Meteorology Ionosphere and Climate (COSMIC) mission (July 2006December 2016) supplemented with data from the Gravity Recovery and Climate Experiment (GRACE; 2007-16) and X-band TerraSAR satellite (TerraSAR-X; 2012-16) missions, with an average of 40000 soundings per month.

Since there is a difference in the frequency of observations between the two missions, we calculated the 
TABLE 1. Horizontal resolution, vertical levels, and time period for each dataset used in this study.

\begin{tabular}{lccr}
\hline \multicolumn{1}{c}{ Dataset } & Horizontal resolution & Vertical levels & Time period \\
\hline $\begin{array}{l}\text { GPS-RO (Anthes et al. 2008; Leroy } \\
\text { et al. 2012) }\end{array}$ & $5^{\circ}$ lat $\times 5^{\circ}$ lon & 71 (starts from 400 hPa) & Mar 2002-Dec 2016 \\
MERRA-2 (Gelaro et al. 2017) & $0.5^{\circ}$ lat $\times 0.625^{\circ}$ lon & 42 (starts from the surface and & Jan 1980-Dec 2017 \\
& & same below) & Jan 1979-Dec 2010 \\
CFSR (Saha et al. 2010) & $0.5^{\circ}$ lat $\times 0.5^{\circ}$ lon & 37 & Jan 2011-Dec 2017 \\
CFSR v2 (Saha et al. 2014) & $0.5^{\circ}$ lat $\times 0.5^{\circ}$ lon & 37 & Jan 1979-Dec 2017 \\
ERA-Interim (Dee et al. 2011) & $0.5^{\circ}$ lat $\times 0.5^{\circ}$ lon & 37 & Jan 1979-Dec 2017 \\
JRA-55 (Kobayashi et al. 2015; Harada & $1.25^{\circ}$ lat $\times 1.25^{\circ}$ lon & & 37 \\
$\quad$ & & & \\
\hline
\end{tabular}

average and root-mean-square of the tropical belt edge latitude differences between the first four years of the dataset (2002-05; CHAMP) and the remainder of the dataset (2006-16; mainly COSMIC). As a reference we also compare the last four years of the dataset (2013-16; mainly COSMIC) and the remainder of the dataset (2002-12; mainly COSMIC). It turns out the differences have larger root mean squares for almost four seasons and four metrics between 2002-05 and 2006-16 than between 2013-16 and 2002-12. The differences can be caused by the year-to-year variabilities, HC expansion, and dataset differences. However, the average differences are always smaller than $1.5^{\circ}$. Thus, it appears that the tropopause is less constrained in the CHAMP data, but we do not detect any systematic change that can be attributed to the change in instrumentation during the 15 years that we examine.

GPS-RO is well suited for studying the tropical tropopause region owing to its precision in the upper troposphere and lower stratosphere (Anthes et al. 2008; Staten and Reichler 2008). It has thus been widely used to study the tropical tropopause and tropical belt (Seidel and Randel 2007; Birner 2010; Davis and Birner 2013; Ao and Hajj 2013), including the discontinuity between the high tropical tropopause and the lower extratropical tropopause (Son et al. 2011; Ao and Hajj 2013; Gao et al. 2015; MK18). Because of the irregular distribution of GPS-RO data, Bayesian interpolation has been used (Leroy et al. 2012; Verkhoglyadova et al. 2014) to optimize the mapping of monthly GPS-RO soundings using spherical harmonic functions up to 14 th degree. The GPS-RO dataset used in this study is computed at a $5^{\circ}$ latitude $\times 5^{\circ}$ longitude grid at 71 fixed pressure levels between 400 and $50 \mathrm{hPa}$ and spans from March 2002 to December 2016.

In this paper, the tropopause is defined by using the World Meteorological Organization (WMO) definition (WMO 1957), which is "the lowest level at which the lapse rate decreases to $2^{\circ} \mathrm{C} / \mathrm{km}$ or less, provided also the average lapse rate between this level and all higher levels within $2 \mathrm{~km}$ does not exceed $2^{\circ} \mathrm{C} / \mathrm{km}$ " (p. 137). To calculate the seasonal and annual mean tropopause, data are averaged either seasonally or annually before calculating the tropopause and the tropopause break metrics. In contrast, Ao and Hajj (2013) and MK18 calculated instantaneous tropopause heights from GPS-RO profiles, before calculating monthly averages over grid bins. Note that the diagnostic of the average field is different from the average of the diagnostic field. Although similar results can be gotten from the zonal mean (Gettelman et al. 2009), different averaging methods can matter at a regional level.

\section{b. Reanalyses}

We analyze data from the following four reanalyses: Modern-Era Retrospective Analysis for Research and Applications, version 2 (MERRA-2; Gelaro et al. 2017), Climate Forecast System Reanalysis (CFSR) and CFSR version 2 (v2) (Saha et al. 2010, 2014), Japanese 55-Year Reanalysis (JRA-55; Kobayashi et al. 2015; Harada et al. 2016), and European Centre for Medium-Range Weather Forecasts interim reanalysis (ERA-Interim; Dee et al. 2011). The horizontal resolution, vertical levels, and time period of the reanalyses are listed along with those for the GPSRO dataset in Table 1. Temperature and geopotential height fields from these data are examined at their original, $2.5^{\circ} \times 2.5^{\circ}$, and $5^{\circ} \times 5^{\circ}$ resolutions to investigate the resolution impact. The latter (i.e., $5^{\circ} \times 5^{\circ}$ ) is comparable to that for the GPS-RO observation dataset (Leroy et al. 2012). Besides temperature and geopotential height, ERA-Interim 200 -hPa $u$-wind is also used to study the meaning of metric in section $3 \mathrm{~b}$.

\section{c. Metrics}

We use four metrics related to the TTB-or the sharp transition from a high tropical tropopause to a low extratropical tropopause-to study the regional tropical belt (see Fig. 1). The four metrics include two subjective metrics and two objective metrics. All are calculated for each individual longitude, with 
GPS-RO $\left(165^{\circ} \mathrm{W}\right)$ tropopause, metrics

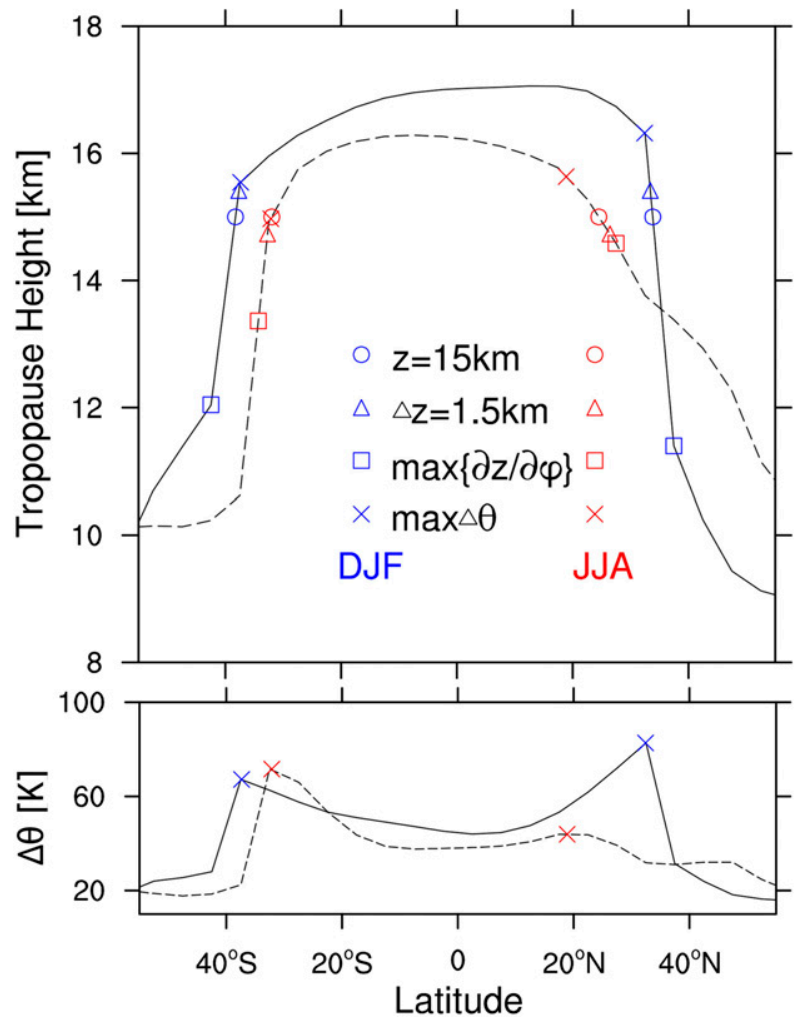

FIG. 1. Latitudes of (top) the four metrics analyzed during JJA (red symbols) and DJF (blue symbols) based on the lapse-rate tropopause (solid lines for DJF and dashed for JJA) and (bottom) potential temperature difference between $400 \mathrm{hPa}$ and tropopause with marked $\max \Delta \theta$ metric. A 15 -yr average tropopause at $165^{\circ} \mathrm{W}$ in GPS-RO is used.

$\max (\partial Z / \partial \varphi)$ and $\max \Delta \theta$ metrics using routines from the Tropical-Width Diagnostic (Trop-D) software package (Adam et al. 2018). The four metrics are the following:

1) Metric $z=15 \mathrm{~km}$ is the latitude at which the tropopause height equals $15 \mathrm{~km}$, which is a frequently used but arbitrary threshold for the tropical edge (Seidel and Randel 2007; Lu et al. 2009). Although some studies use this method to define annual tropopause, this metric can also be applied for a shorter time average like a season (Seidel and Randel 2007; Davis and Rosenlof 2012).

2) Metric $\Delta Z=1.5 \mathrm{~km}$ is the latitude at which the tropopause height falls $1.5 \mathrm{~km}$ below the average tropopause height between $15^{\circ} \mathrm{S}$ and $15^{\circ} \mathrm{N}$ (Davis and Rosenlof 2012). This metric is similar to the previous one but allows for variations in the tropical tropopause height.

3) Metric $\max (\partial Z / \partial \varphi)$ is the latitude of the largest meridional tropopause height gradient (Davis and
Rosenlof 2012). This method has been modified regionally by picking the equatorward of the two maxima over the North Pacific and Atlantic Oceans $\left(150^{\circ} \mathrm{E}-130^{\circ} \mathrm{W}\right.$ and $\left.0^{\circ}-70^{\circ} \mathrm{W}\right)$ during June-August (JJA) and the North Atlantic Ocean $\left(0^{\circ}-70^{\circ} \mathrm{W}\right)$ during September-November (SON), because of the presence of a second tropopause break (see the JJA curve in Fig. 1). This metric is intended to be more objective than the previous ones that are based on subjective thresholds.

4) Metric $\max \Delta \theta$ is the latitude of the largest dry bulk static stability (Davis and Birner 2013). We calculate the stability for the layer between $400 \mathrm{hPa}$ and tropopause because the lowest level in the GPS-RO satellite data used is $400 \mathrm{hPa}$. The bulk static stability has been calculated from both $400 \mathrm{hPa}$ and the surface (see Fig. S1 in the online supplemental material) as the lower layer, and they both have obvious maximums at certain latitudes that can be used to depict the edge of the tropics. When comparing the tropical belt edge, they agree most of the time in both hemispheres except for the Northern Hemisphere (NH) JJA, with the one calculated from $400 \mathrm{hPa}$ better depicting the edge.

In addition to the four metrics that we calculate ourselves, we analyze the following six zonal-mean metrics (see also Solomon et al. 2016; Davis and Birner 2017) calculated by the CLIVAR (Climate Variability and Predictability Program) group (available with the TropD software):

1) TPB is the $\max (\partial Z / \partial \varphi)$ metric, but calculated previously by the CLIVAR group. It appears to be almost identical, and is very highly correlated $\left(0.93^{*}\right.$; hereinafter an asterisk indicates that the correlation is significant at $5 \%$ level, based on the Student's $t$ test in the text) with our own calculation.

2) EDJ is the eddy-driven jet, based on the latitude of the maximum of the zonal-mean westerly wind at $850 \mathrm{hPa}$ : although it is not a metric of tropical width, the eddy-driven jet often varies with some metrics for the tropical edge.

3) SLP is the subtropical ridge, or the latitude of the maximum zonal-mean sea level pressure.

4) The psi500 is the traditional HC definition, calculated from the zero crossing of the mass streamfunction at $500 \mathrm{hPa}$, calculated from the zonal-mean meridional wind.

5) STJ is the subtropical jet, based on the maximum of the $100-400-\mathrm{hPa}$ zonal-mean zonal wind, after removing the $850-\mathrm{hPa}$ zonal wind. 
GPS-RO Tropopause breaks
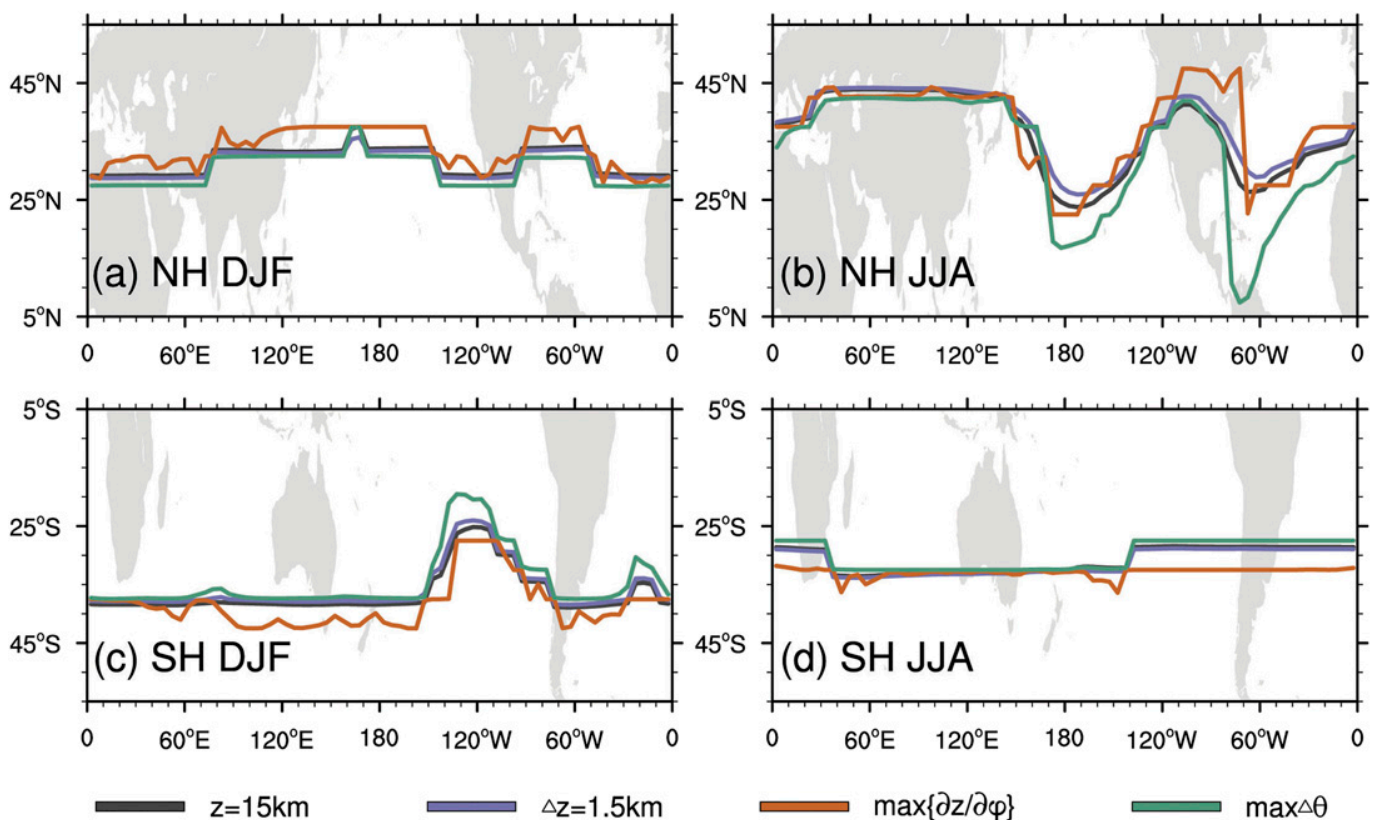

FIG. 2. Seasonal mean TTB latitudes derived using the four metrics and represented by various line colors, from GPS-RO data during 2002-16 over the (a),(b) NH and (c),(d) SH during (left) DJF and (right) JJA. Note that in Figs. 2-5, line hue represents the metric, line lightness represents the resolution (with the dark shades here representing $5^{\circ}$ ), and line style represents the dataset (with solid here representing GPS-RO).

6) USFC is the transition latitude of the surface zonalmean zonal easterly wind changes to westerly.

\section{Results}

In this section, we will 1) document the climatology of regional, seasonal TTB structures, 2) validate the TTB as depicted in reanalyses, and 3) determine the sensitivity of the regional tropical belt edge and its variation and change to the data source, to the data resolution, or to the TTB metric employed.

\section{a. The regional, seasonal tropical edge in GPS-RO data}

The seasonal tropical belt edge varies longitudinally, which is different from season to season. From winter to summer over the NH (see Fig. 2; also in the online supplemental material see Fig. S2 for the equinoctial seasons and Fig. S3 for reanalyses), the TTB generally shifts poleward over the land (as in MK18); this is true for all four TTB metrics. Over the ocean, however, the metrics often differ-by as much as $20^{\circ}$, as occurs over the NH Atlantic Ocean during JJA (see Fig. 2b; this is in contrast to MK18). Although the difference between metrics can be as large as $40^{\circ}$ latitude from longitude to longitude, it is because of sharp east-west transitions occurring slightly to the east in one metric relative to the other; the great-circle distance between the two curves is never more than $20^{\circ}$. But, in general, the TTB metrics agree most closely during the solstitial seasons (see supplemental Fig. S2). Over the SH, TTB metrics consistently depict (within $10^{\circ}$ of one another) a mostly zonal TTB, shifting poleward during December-February (DJF) (to about $35^{\circ} \mathrm{S}$; Fig. 2c), and equatorward during JJA (to about $30^{\circ} \mathrm{S}$; Fig. $2 \mathrm{~d}$ ), except over the eastern Pacific Ocean during DJF, where the TTB extends equatorward to $20^{\circ}-30^{\circ} \mathrm{S}$, depending on the metric. The seasonal cycles and the regional differences over the ocean are consistent between datasets (see supplemental Fig. S3 and MK18).

The large differences between metrics seem to indicate wide tropical tropopause transition regions, rather than crisp climatological cutoffs. Compared to other longitudes, these tropical tropopause transition regions, from daily tropopause height maps (not shown), experience recurrent, persistent low-tropopause incursions from the storm tracks just in the upstream. Even though the day-to-day tropopause break may be well defined, this mixing on synoptic time scales smooths out the temperature field, suppressing the STJ (see MK18) and smoothing the TTB on seasonal time scales (see the cross section at $165^{\circ} \mathrm{W}$ in Fig. 1), making metrics 
Tropopause breaks from different datasets

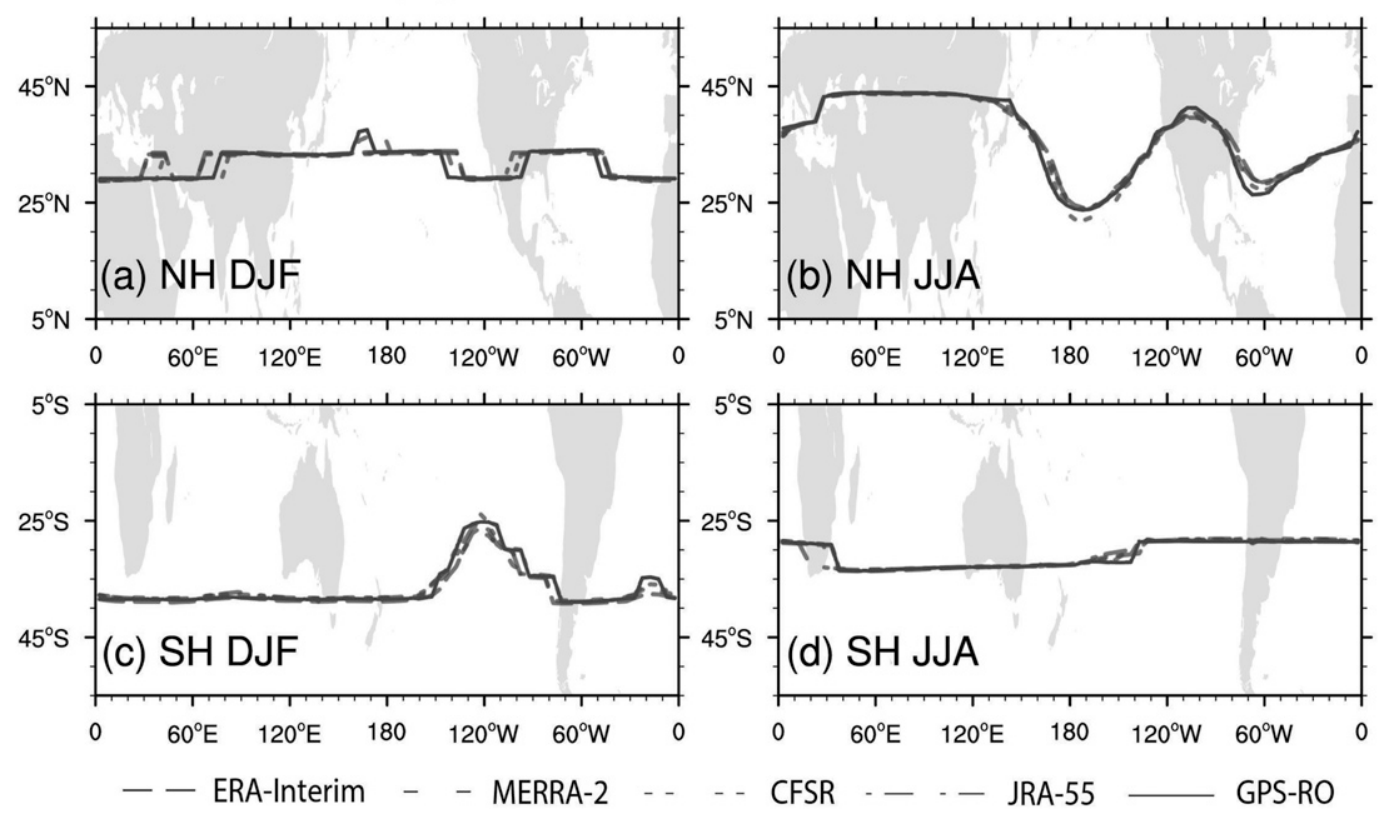

FIG. 3. Seasonal mean TTB latitudes based on the $z=15 \mathrm{~km}$ metric, calculated from the GPS-RO and four reanalyses (see the line style) with a resolution of $5^{\circ} \times 5^{\circ}$ during 2002-16 over the (a),(b) NH and (c),(d) SH during (left) DJF and (right) JJA.

sensitive to small perturbations. For a smooth temperature gradient, small perturbations can cause large differences in threshold metrics such as the tropopause itself-doubly so for the tropopause break. This is also true for the maximum metric, as tropospheric static stability varies from east to west, and, for a given longitude, $\Delta \theta$ can have multiple maxima. Among the four metrics, the $\max \Delta \theta$ tends to be the most equatorward, while the $\max (\partial Z / \Delta \varphi)$ tends to be the most poleward, and the $z=15 \mathrm{~km}$ and $\Delta Z=1.5 \mathrm{~km}$ metrics are clustered more tightly in between.

Why MK18 do not show similar large differences between metrics in the tropopause transition regions is unclear. We initially speculated that the difference was related to our decision to average the data prior to calculating the tropopause and metrics. But calculating the metrics before averaging results in even larger disagreements over larger areas (not shown).

\section{b. Reanalysis validation}

Reanalyses are widely used in tropical belt studies (Davis and Birner 2013, 2016, 2017; Ao and Hajj 2013) and the choice of dataset can impact the calculated climatological width and trends in the zonal-mean tropical belt width (Davis and Birner 2017). Here, we use four modern reanalyses to study the regional tropical belt in comparison with the GPS-RO satellite data and we examine the impact of the choice of dataset on tropical belt edge determination. Specifically, we compare tropical width metrics calculated from four modern reanalyses and GPS-RO satellite data, all interpolated into $5^{\circ} \times 5^{\circ}$ (Fig. 3; see Fig. S4 in the online supplemental material for equinoctial seasons, with other metrics being in Fig. S5) and at their original resolutions (see supplemental Fig. S6). In comparison with the choice of metric, the choice between datasets examined in this study makes a comparatively small difference (generally less than $\left.10^{\circ}\right)$. Although the $\max (\partial Z / \partial \varphi)$ metric differs by as much as $30^{\circ}$ in SH DJF (plot "D 1 " in supplemental Fig. S5), this can also be considered as the existence of sharp east-west transitions between one dataset to the other besides an obvious poleward spike from JRA-55; the great-circle distance between the curves is generally within $10^{\circ}$.

Of course, the dataset differences above are minimized by using the same resolution. In their metareview, Davis and Birner (2016) show that a finer horizontal resolution in model can cause a narrower tropical belt in the zonal mean. Totz et al. (2018) find differences in regional trends in ERA-Interim and National Centers for Environmental Prediction-National Center for Atmospheric Research reanalysis (NNR) data with different resolutions and posit that the discrepancy might be due to differences in resolution, although they use the meridional streamfunction, which has its own issues with trends in reanalyses (Davis and Davis 2018). For example, in NH 


\section{ERA-Interim Tropopause breaks}

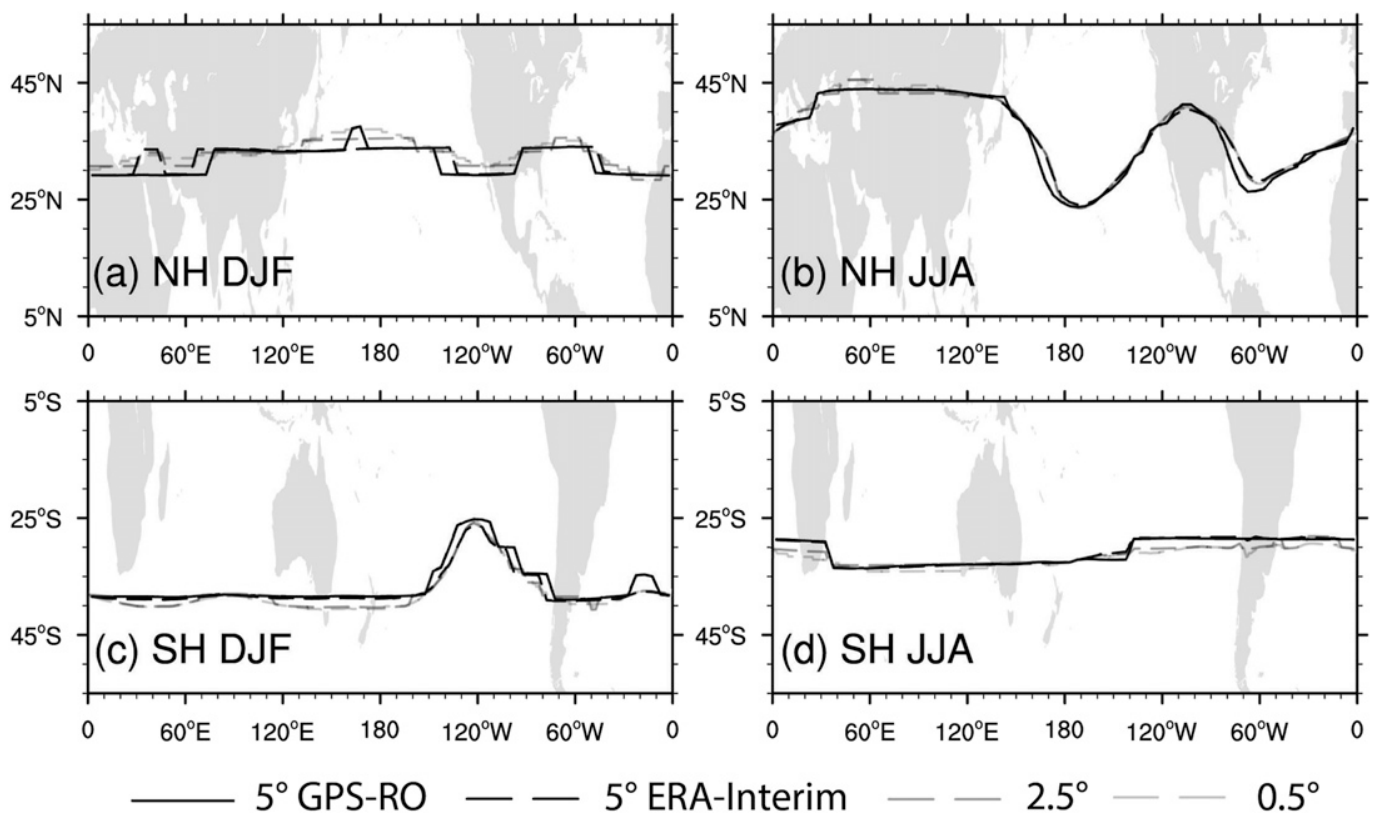

FIG. 4. Seasonal mean TTB latitudes according to the $z=15 \mathrm{~km}$ metric, calculated from ERA-Interim and interpolated to different resolutions (by the line lightness) during 2002-16 over the (a),(b) NH and (c),(d) SH during (left) DJF and (right) JJA.

winter, there is a poleward shifting trend of the $\mathrm{HC}$ edge over the central Pacific from ERA-Interim data. However, there is a significant equatorward shifting of the $\mathrm{HC}$ edge in the same region calculated from the NNR dataset. Since we are looking at the regional tropical belt and the data used to find edge can have different resolutions, we will then discuss whether resolution will make a difference in depicting the tropical belt edge.

To examine the impact of resolution on the regional tropical tropopause, we compare reanalysis data at the original resolution with the same data interpolated to a $2.5^{\circ}$ grid and a $5^{\circ}$ grid (Fig. 4 ; see Fig. S7 in the online supplemental material for equinoctial seasons, with other metrics and datasets being in supplemental Figs. S8-S11). In general, the differences between resolutions (Fig. 4) are slightly larger than the differences between the datasets when all interpolated to $5^{\circ}$ (Fig. 3), but much smaller than the differences between metrics (Fig. 2). But with different resolutions, qualitatively the same structure in the tropopause is detected for all metrics and datasets, with the exception that the $\max (\partial Z / \partial \varphi)$ values from MERRA-2 over the Pacific Ocean in NH SON (see plot "E 4" in Fig. S6 of the online supplemental material) and SH DJF (see plot "F 1" in Fig. S6) do not match those from others. It is worth noting that the GPS-RO dataset used here is gridded at about 3 times the vertical resolution of the gridded reanalysis outputs. However, different datasets depict similar tropical belt edges. Thus, while the tropopause height itself is sensitive to the vertical resolution of the dataset (Reichler et al. 2003; Seidel and Randel 2006; Ao and Hajj 2013), the horizontal extent of the tropics is less so.

The regional differences due to metric and resolution would alias onto the zonal mean (ERA-Interim data in Fig. 5; see Figs. S12-S14 in the online supplemental material for other datasets). Here again, however, the differences due to metric are several degrees larger than the differences due to resolution, except during July, when the $\max (\partial Z / \partial \varphi)$ metric shows a sensitivity to resolution on par to the differences between metrics.

From year to year during 2003-16 for the interannual variation, the total tropical belt width calculated from $z=15 \mathrm{~km}$ and $\Delta Z=1.5 \mathrm{~km}$ metrics are well correlated $\left(\sim 0.9^{*}\right)$ between datasets. As shown in Table 2, even accepting the GPS-RO as the standard, it is hard to determine which dataset is the most accurate. Judging from the 14-yr trend, CFSR appears the most realistic by far. On the other hand, judging from year-to-year correlations, MERRA-2 has a slight edge over CFSR, and in general most reanalyses perform similarly. This suggests that high year-to-year correlations do not necessarily imply a more realistic trend. In addition, depending on the metric and dataset, the mixture of 


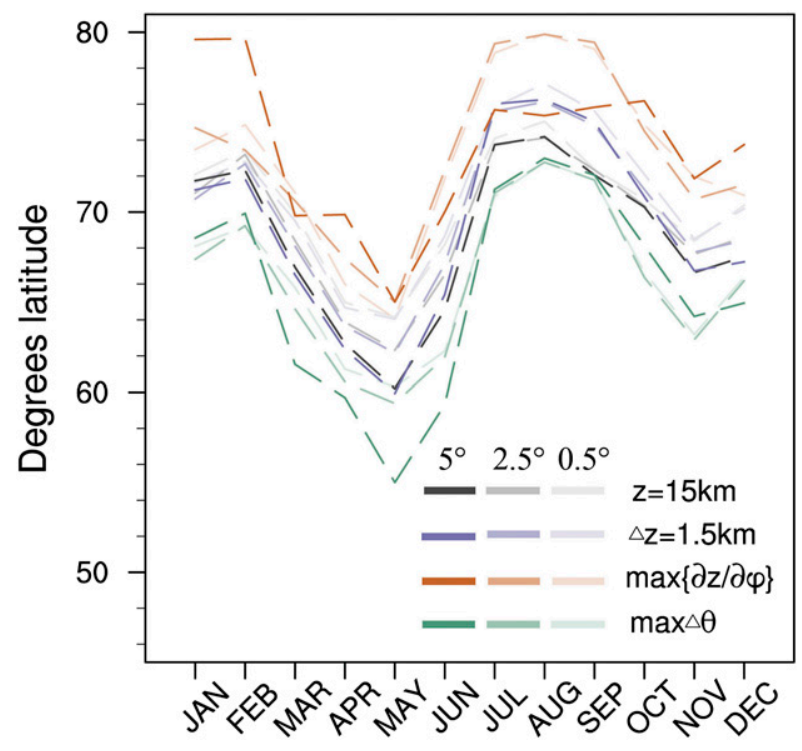

FIG. 5. Zonal-mean monthly tropical belt width calculated from ERA-Interim during 1979-2017.

widening and contracting tropical belt width trends from 2003 to 2016 bears no resemblance to the almost universally widening trends from 1979 to 2017. From this, we conclude that the time period of GPS-RO is too short to verify the tropical belt widening trends in reanlayses.

\section{c. The tropopause breaks and other metrics}

Having validated the depiction of the TTB in reanalyses in terms of the seasonal and regional climatology structures and zonal-mean interannual variability, we extend the metric intercomparison work of U.S. CLIVAR and ISSI (International Space Science Institute) groups (Solomon et al. 2016; Waugh et al. 2018), focusing here on the relationship between four TTB metrics and other tropical width metrics in reanalysis data, via analysis of deseasonalized correlations and regressed wind patterns in the following two sections.

\section{1) Correlations Between Metrics}

Here we examine the correlations between our TTB metrics and each other, and between other metrics of tropical width. While examining seasonal mean data, Solomon et al. (2016) and Waugh et al. (2018) noted that tropical width metrics would be roughly grouped into "lower" metrics, including the $\mathrm{HC}$ edge (500-hPa streamfunction), and "upper" metrics, including the STJ and TTB (note the high correlations in the lowerleft quadrant of the correlation table in Fig. 6). Similar evidence can also be found in Davis and Birner (2017). MK18, on the other hand, noted a higher correlation $\left(r=0.61^{*}\right)$ between the "upper" tropical tropopause width and the "lower" HC anomaly, but in the annual mean data, leading us to question the cause of the disparity. Also, through a joint empirical orthogonal function analysis, Amaya et al. (2018) find similar internal and forced modes between the HC and TTB, which indicates there could be certain relationship between them. Davis and Birner (2013) note a onemonth lag between the tropopause break metric and the HC, which may explain the lower seasonal correlations (see also Solomon et al. 2016). Model shortcomings may result in smaller correlations (Davis and Birner 2016; see also Johanson and Fu 2009; Hu et al. 2013; Quan et al. 2014). In addition, the shortness of the reanalysis record may more readily result in spurious correlations.

As expected, the annual mean tropical width based on the TTB metric is well correlated with the STJ $\left(r=0.64^{*}\right.$; see Fig. S15 in the online supplemental material), and less well correlated with the other metrics, although the annual mean correlation between the TTB and the HC width is higher $\left(r=0.49^{*}\right)$ than that in the seasonal mean

TABLE 2. Correlations between GPS-RO and reanalyses during 2003-16 (an asterisk indicates that the correlation is significant at the 5\% level of the Student's $t$ test).

\begin{tabular}{|c|c|c|c|c|c|}
\hline & & MERRA-2 & CFSR & ERA-Interim & JRA-55 \\
\hline \multirow[t]{3}{*}{$z=15 \mathrm{~km}$} & $\mathrm{NH}$ & $0.73^{*}$ & $0.62^{*}$ & 0.45 & $0.94^{*}$ \\
\hline & $\mathrm{SH}$ & $0.79^{*}$ & $0.81^{*}$ & $0.88^{*}$ & $0.68^{*}$ \\
\hline & Total width & $0.7^{*}$ & $0.62^{*}$ & 0.41 & $0.91^{*}$ \\
\hline \multirow[t]{3}{*}{$\Delta Z=1.5 \mathrm{~km}$} & NH & $0.87^{*}$ & $0.72^{*}$ & $0.61^{*}$ & $0.96^{*}$ \\
\hline & $\mathrm{SH}$ & $0.94^{*}$ & $0.91^{*}$ & $0.9^{*}$ & $0.79^{*}$ \\
\hline & Total width & $0.88^{*}$ & $0.75^{*}$ & $0.63^{*}$ & $0.94^{*}$ \\
\hline \multirow[t]{3}{*}{$\max (\partial Z / \partial \varphi)$} & $\mathrm{NH}$ & $0.81^{*}$ & $0.74^{*}$ & $0.66^{*}$ & $0.83^{*}$ \\
\hline & $\mathrm{SH}$ & 0.43 & $0.56^{*}$ & $0.6^{*}$ & 0.48 \\
\hline & Total width & $0.68^{*}$ & $0.56^{*}$ & $0.66^{*}$ & 0.4 \\
\hline \multirow[t]{3}{*}{$\max \Delta \theta$} & NH & $0.86^{*}$ & $0.75^{*}$ & $0.65^{*}$ & $0.89^{*}$ \\
\hline & $\mathrm{SH}$ & 0.47 & $0.82^{*}$ & 0.29 & $0.97^{*}$ \\
\hline & Total width & $0.85^{*}$ & $0.77^{*}$ & $0.6^{*}$ & $0.56^{*}$ \\
\hline
\end{tabular}




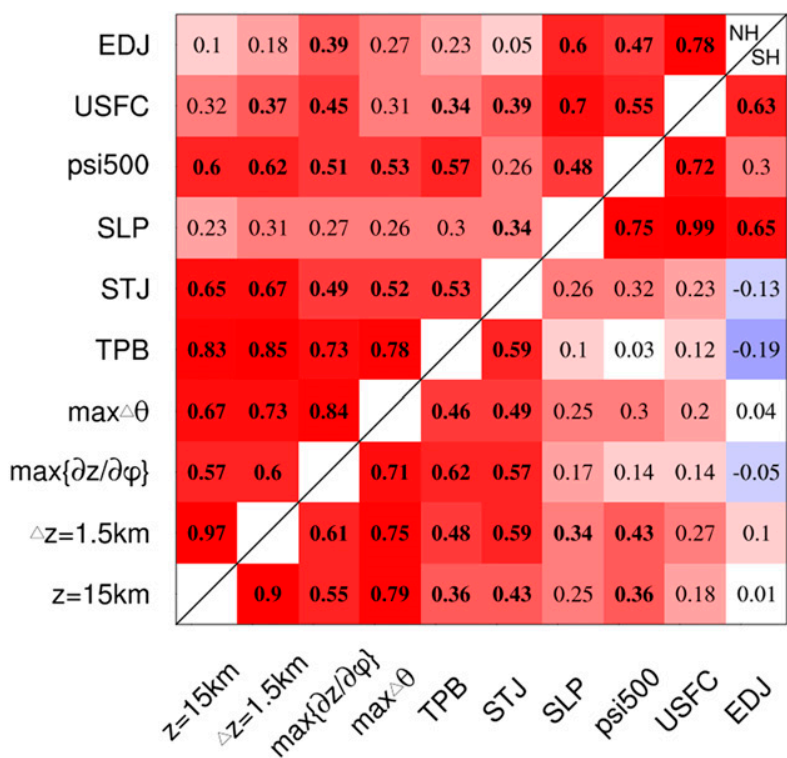

FIG. 6. Year-to-year correlations (boldface numbers are significant at the $5 \%$ level, based on the Student's $t$ test) between annualmean metrics during 1979-2016 using ERA-Interim data over each hemisphere (with NH correlations in the top left and SH correlations in the bottom right), calculated from the four TTB metrics in our study (at bottom left) and six tropical belt metrics from the U.S. CLIVAR online database: TPB $=\max (\partial Z / \partial \varphi)$ metric, but calculations performed by the CLIVAR group; EDJ = eddy-driven jet; SLP = subtropical ridge, or sea level pressure maximum; psi500 = traditional Hadley cell definition; USFC $=$ surface wind zero crossing; and STJ = subtropical jet.

model data (Waugh et al. 2018). Results are similar for other TTB metrics (see supplemental Figs. S16-S18). When looking at TTB in each hemisphere separately (Fig. 6), the correlations between TTB metrics are high. The upper-versus-lower metric clustering is evident over the $\mathrm{SH}$, which could be due to fewer data constraining the reanalyses there, or to different dynamics in eddydriven and subtropical jets, while over the NH the TTB metrics are also moderately correlated $\left(0.51^{*}-0.62^{*}\right)$ with the psi500 metric. It is noted that the correlation

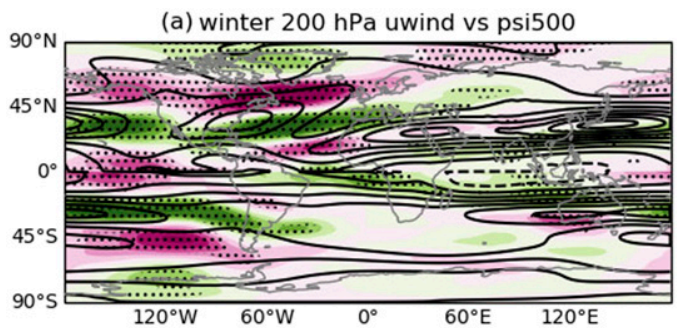

between the GPS-RO-derived TTB and ERA-Interimderived lower metrics become even higher than that between the TTB and lower metrics both based on ERA-Interim.

\section{2) The MEANING OF TTB METRICS}

Noting that TTB metrics correspond more closely temporally (Fig. 6) to the STJ metric than to the HC metric, we investigate the regional pattern of $200-\mathrm{hPa}$ zonal wind coinciding with year-to-year changes in the $\mathrm{HC}$ edge and the zonal-mean TPB [based on metric $\max (\partial Z / \partial \varphi)]$ in the winter (Fig. 7). Changes in the zonal wind associated with $\mathrm{HC}$ (Fig. 7a) include a weakening of the STJ over the Pacific-a pattern that projects onto the zonal mean (Waugh et al. 2018; Menzel et al. 2019). The Pacific is likely where some of the strongest coupled changes in the regional overturning circulation occur when the zonal-mean HC is wider (Staten et al. 2019). At other longitudes, a poleward shift in the STJ can be seen (note the intensification poleward of the jet on the west coast of Australia, for example). In contrast, a poleward shift in the TPB (Fig. 7b) reflects a nearly zonal poleward shift in the STJ at most longitudes.

\section{Summary}

We analyze the TTB in GPS-RO and reanalyses to address three objectives: 1) document the regional, seasonal structure of the TTB; 2 ) validate the TTB as depicted in reanalyses; and 3) determine which of the differences in previous studies can be attributed to the data source, the data resolution, and the TTB metric employed. Here we summarize our results ordered by objective, before concluding.

\section{a. Objective 1: TTB structure}

We use the TTB to study the tropical width at a regional level using both GPS-RO observations and

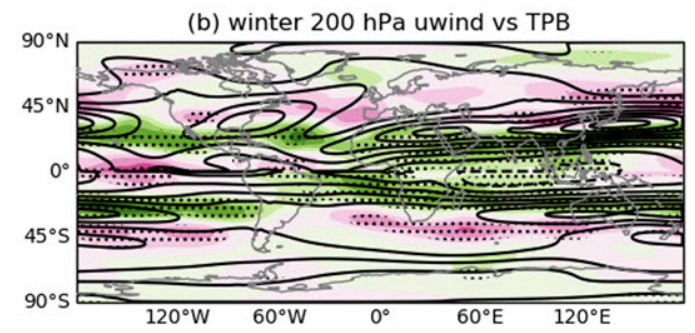

$\mathrm{m} \mathrm{s}^{-1} \cdot \mathrm{lat}^{-1}$

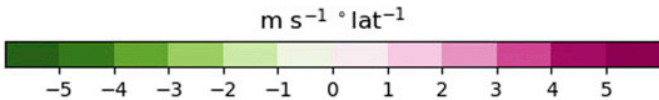

FIG. 7. Climatological zonal wind (contours, dashed for negative) as well as $200-\mathrm{hPa}$ zonal wind regressed (shading) onto poleward shifts in (a) the HC edge in each hemisphere and (b) the TPB in each hemisphere. These winter regressions are for DJF over the $\mathrm{NH}$ and JJA over the $\mathrm{SH}$. 
reanalyses. Over the land, the TTB with all four TTB metrics is displaced poleward relative to its wintertime position. Over the ocean, the TTB with all metrics is displaced poleward during winter.

Spatially, the TTB qualitatively resembles the STJ (see Fig. 1 from Manney and Hegglin 2018) rather than the regional extent of the HC (see Fig. 2 from Staten et al. 2019). Temporally, the TTB is more closely correlated with the STJ, a correlation that is manifested in regression maps of zonal wind.

\section{b. Objective 2: TTB in reanalyses}

Reanalyses with different resolutions overall show consistent seasonal TTB patterns and they are close to the GPS-RO satellite data. Indeed, once differences in the resolution are accounted for, the differences in the TTB between the four modern reanalyses are smaller than the differences in the TTB between different resolutions for the same reanalysis, or between different metrics for the same dataset. We interpret this as a validation of the reanalyses themselves, but also as a caveat when interpreting previous results from multiple datasets: anomalies due to output resolution may be incorrectly interpreted as shortcomings of a reanalysis itself.

\section{c. Objective 3: TTB metric sensitivities}

The dominant influence of the choice of metric over output resolution or the choice of reanalysis illustrates the care that must be taken when performing (or comparing between) investigations into tropical width. Waugh et al. (2018) and MK18 appear at first to disagree, but the differences between the correlations in the two studies appear to be explained by the time period and hemisphere (or hemispheres) over which averages are performed. The ordering of processing steps can also have a large impact at the regional level; averaging instantaneously calculated metrics (not shown) can produce large differences between TTB metrics, but this does not explain the differing sensitivity to metric over the NH Pacific during JJA between our study and MK18.

\section{d. Conclusions}

We conclude that the GPS-RO tropical belt broadly resembles that in most reanalyses spatially and temporally, once metrics and resolution are accounted for. To achieve the best agreement, reanalyses must first be degraded in resolution to match the $5^{\circ}$ GPS-RO grid, so either the $z=15 \mathrm{~km}$ or $\Delta Z=1.5 \mathrm{~km}$ metrics must be used. Unfortunately, these first two metrics are subjective, and react differently to tropical widening (Waugh et al. 2018), so we cannot recommend any single metric over the others in tropical widening studies.

Despite the disagreement in the zonal mean, the regional TTB is similar in most datasets. We recommend further examination of the regional TTB to discern why the metrics agree over the $\mathrm{NH}$, where the subtropics are more regionally defined, but not over the $\mathrm{SH}$, where the subtropics are more globally defined. We also recommend examining the regional structure of the tropical edge in various metrics beyond the TTB in order to physically interpret the statistical relationships between metrics in the zonal mean.

The four metrics also differ in their depiction of the southern edge of the tropics from year to year. Over the $\mathrm{NH}$, the metrics agree with each other, but the reanalyses do not. In the same context, CFSR has the most real 14-yr trend by far. Because of the shortness of the GPS-RO record, however, concluding that CFSR trends are the most accurate seems premature, and we could not come up with a best match of the GPS-RO.

Acknowledgments. Part of the work was performed while funded by National Science Foundation (NSF) (Grant 1813981). We acknowledge Dr. Olga Verkhoglyadova of Jet Propulsion Laboratory (JPL) for GPS-RO data. Work performed by Chi O. Ao was carried out at the JPL, California Institute of Technology, under a contract with the National Aeronautics and Space Administration. MERRA2, CFSR, ERA-Interim, and JRA-55 reanalyses are carried out by NASA's Global Modeling and Assimilation Office (GMAO), National Centers for Environmental Prediction (NCEP), European Centre for Medium-Range Weather Forecasts (ECMWF), and Japan Meteorological Agency (JMA) respectively. We also thank the CLIVAR and ISSI working groups for the tropical belt metrics and Trop-D method by Adam et al. (2018), which we include in the calculation of metrics $\max (\partial Z / \partial \varphi)$ and $\max \Delta \theta$.

\section{REFERENCES}

Adam, O., and Coauthors, 2018: The TropD software package (v1): Standardized methods for calculating tropical-width diagnostics. Geosci. Model Dev., 11, 4339-4357, https://doi.org/10.5194/ gmd-11-4339-2018.

Amaya, D. J., N. Siler, S.-P. Xie, and A. J. Miller, 2018: The interplay of internal and forced modes of Hadley cell expansion: Lessons from the global warming hiatus. Climate Dyn., 51, 305-319, https://doi.org/10.1007/s00382-017-3921-5.

Anthes, R. A., and Coauthors, 2008: The COSMIC/FORMOSAT3 mission: Early results. Bull. Amer. Meteor. Soc., 89, 313-334, https://doi.org/10.1175/BAMS-89-3-313.

Ao, C. O., and A. J. Hajj, 2013: Monitoring the width of the tropical belt with GPS radio occultation measurements. Geophys. Res. Lett., 40, 6236-6241, https://doi.org/10.1002/2013GL058203. 
Barnes, E. A., and L. Polvani, 2013: Response of the midlatitude jets, and of their variability, to increased greenhouse gases in the CMIP5 models. J. Climate, 26, 7117-7135, https://doi.org/ 10.1175/JCLI-D-12-00536.1.

Birner, T., 2010: Recent widening of the tropical belt from global tropopause statics sensitivities. J. Geophys. Res., 115, D23109, https://doi.org/10.1029/2010JD014664.

Ceppi, P., and D. L. Hartmann, 2013: On the speed of the eddydriven jet and the width of the Hadley cell in the Southern Hemisphere. J. Climate, 26, 3450-3465, https://doi.org/10.1175/ JCLI-D-12-00414.1.

—, M. D. Zelinka, and D. L. Hartmann, 2014: The response of the Southern Hemispheric eddy-driven jet to future changes in shortwave radiation in CMIP5. Geophys. Res. Lett., 41, 3244 3250, https://doi.org/10.1002/2014GL060043.

— , G. Zappa, T. G. Shepherd, and J. M. Gregory, 2018: Fast and slow components of the extratropical atmospheric circulation response to $\mathrm{CO}_{2}$ forcing. J. Climate, 31, 1091-1105, https:// doi.org/10.1175/JCLI-D-17-0323.1.

Chemke, R., and L. M. Polvani, 2019a: Exploiting the abrupt $4 \times$ $\mathrm{CO}_{2}$ scenario to elucidate tropical expansion mechanisms. J. Climate, 32, 859-875, https://doi.org/10.1175/JCLI-D-180330.1 .

$\longrightarrow$, and $-2019 \mathrm{~b}$ : Opposite tropical circulation trends in climate models and in reanalyses. Nat. Geosci., 12, 528-532, https://doi.org/10.1038/s41561-019-0383-x.

Davis, N. A., and T. Birner, 2013: Seasonal to multidecadal variability of the width of the tropical belt. J. Geophys. Res. Atmos., 118, 7773-7787, https://doi.org/10.1002/JGRD.50610.

— , and - 2016: Climate model biases in the width of the tropical belt. J. Climate, 29, 1935-1954, https://doi.org/10.1175/ JCLI-D-15-0336.1.

— sion between reanalyses and climate models and among tropical belt width metrics. J. Climate, 30, 1211-1231, https:// doi.org/10.1175/JCLI-D-16-0371.1.

_ , and S. M. Davis, 2018: Reconciling Hadley cell expansion trend estimates in reanalyses. Geophys. Res. Lett., 45, 11439 11 446, https://doi.org/10.1029/2018GL079593.

,-- , and D. W. Waugh, 2018: New insights into tropical belt metrics. U.S. CLIVAR Variations, No. 16, Washington, D.C., 1-7, https://doi.org/10.5065/D69Z93QF.

Davis, S. M., and K. H. Rosenlof, 2012: A multidiagnostic intercomparison of tropical-width time series using reanalyses and satellite observations. J. Climate, 25, 1061-1078, https://doi.org/ 10.1175/JCLI-D-11-00127.1.

Dee, D. P., and Coauthors, 2011: The ERA-Interim reanalysis: Configuration and performance of the data assimilation system. Quart. J. Roy. Meteor. Soc., 137, 553-597, https://doi.org/ 10.1002/qj.828.

Feng, S., and Q. Fu, 2013: Expansion of global drylands under a warming climate. Atmos. Chem. Phys., 13, 10 081-10094, https://doi.org/10.5194/acp-13-10081-2013.

Fu, Q., and P. Lin, 2011: Poleward shift of subtropical jets inferred from satellite-observed lower-stratospheric temperatures. J. Climate, 24, 5597-5603, https://doi.org/10.1175/ JCLI-D-11-00027.1.

_ - C. M. Johanson, J. M. Wallace, and T. Reichler, 2006: Enhanced mid-latitude tropospheric warming in satellite measurements. Science, 312, 1179, https://doi.org/10.1126/ science. 1125566

Gao, P., X. Xu, and X. Zhang, 2015: Characteristics of the trends in the global tropopause estimated from COSMIC radio occultation data. IEEE Trans. Geosci. Remote Sens., 53, 6813-6822, https://doi.org/10.1109/TGRS.2015.2449338.

Gelaro, R., and Coauthors, 2017: The Modern-Era Retrospective Analysis for Research and Applications, version 2 (MERRA-2). J. Climate, 30, 5419-5454, https://doi.org/10.1175/JCLI-D-160758.1.

Gettelman, A., and Coauthors, 2009: The tropical tropopause layer 1960-2100. Atmos. Chem. Phys., 9, 1621-1637, https://doi.org/ 10.5194/acp-9-1621-2009.

Grise, K. M., and Coauthors, 2019: Recent tropical expansion: Natural variability or forced response? J. Climate, 32, 15511571, https://doi.org/10.1175/JCLI-D-18-0444.1.

Harada, Y., and Coauthors, 2016: The JRA-55 Reanalysis: Representation of atmospheric circulation and climate variability. J. Meteor. Soc. Japan, 94, 269-302, https:// doi.org/10.2151/jmsj.2016-015.

Held, I. M., and A. Y. Hou, 1980: Nonlinear axially symmetric circulations in a nearly inviscid atmosphere. J. Atmos. Sci., 37, 515-533, https://doi.org/10.1175/1520-0469(1980)037<0515: NASCIA $>2.0 . \mathrm{CO} ; 2$.

, and B. J. Soden, 2000: Water vapor feedback and global warming. Annu. Rev. Energy Environ.., 25, 441-475, https:// doi.org/10.1146/annurev.energy.25.1.441.

$\mathrm{Hu}$, Y., and Q. Fu, 2007: Observed poleward expansion of the Hadley circulation since 1979. Atmos. Chem. Phys., 7, 52295236, https://doi.org/10.5194/acp-7-5229-2007.

— L. Tao, and J. Liu, 2013: Poleward expansion of the Hadley circulation in CMIP5 simulations. Adv. Atmos. Sci., 30, 790795, https://doi.org/10.1007/s00376-012-2187-4.

Hudson, R. D., M. F. Andrade, M. B. Follette, and A. D. Frolov, 2006: The total ozone field separated into meteorological regimes-Part II: Northern Hemisphere mid-latitude total ozone trends. Atmos. Chem. Phys., 6, 5183-5191, https:// doi.org/10.5194/acp-6-5183-2006.

Johanson, C. M., and Q. Fu, 2009: Hadley cell widening: Model simulations versus observations. J. Climate, 22, 2713-2725, https://doi.org/10.1175/2008JCLI2620.1.

Kobayashi, S., and Coauthors, 2015: The JRA-55 reanalysis: General specifications and basic characteristics. J. Meteor. Soc. Japan, 93, 5-48, https://doi.org/10.2151/jmsj.2015-001.

Kursinski, E. R., G. A. Hajj, J. T. Schofield, R. P. Linfield, and K. R. Hardy, 1997: Observing Earth's atmosphere with radio occultation measurements using the global positioning system. J. Geophys. Res., 102, 23 429-23 465, https://doi.org/10.1029/97JD01569.

Kushner, P. J., I. M. Held, and T. L. Delworth, 2001: Southern Hemisphere atmospheric circulation response to global warming. J. Climate, 14, 2238-2249, https://doi.org/10.1175/ 1520-0442(2001)014<0001:SHACRT $>2.0 . C O ; 2$.

Leroy, S. S., C. O. Ao, and O. Verkhoglyadova, 2012: Mapping GPS radio occultation data by Bayesian interpolation. J. Atmos. Oceanic Technol., 29, 1062-1074, https://doi.org/ 10.1175/JTECH-D-11-00179.1.

L'Heureux, M. L., S. Lee, and B. Lyon, 2013: Recent multidecadal strengthening of the Walker circulation across the tropical Pacific. Nat. Climate Change, 3, 571-576, https://doi.org/ 10.1038/nclimate1840.

Lu, J., G. A. Vecchi, and T. Reichler, 2007: Expansion of the Hadley cell under global warming. Geophys. Res. Lett., 34, L06805, https://doi.org/10.1029/2006GL028443.

, G. Chen, and D. M. W. Frierson, 2008: Response of the zonal mean atmospheric circulation to El Niño versus global warming. J. Climate, 21, 5835-5851, https://doi.org/10.1175/ 2008JCLI2200.1. 
— C. Deser, and T. Reichler, 2009: Cause of the widening of the tropical belt since 1958. Geophys. Res. Lett., 36, L03803, https://doi.org/10.1029/2008GL036076.

Lucas, C., and H. Nguyen, 2015: Regional characteristics of tropical expansion and the role of climate variability. J. Geophys. Res. Atmos., 120, 6809-6824, https://doi.org/10.1002/2015JD023130.

Manney, G. L., and M. I. Hegglin, 2018: Seasonal and regional variations of long-term changes in upper-tropospheric jets from reanalyses. J. Climate, 31, 423-448, https://doi.org/ 10.1175/JCLI-D-17-0303.1.

Mathew, S. S., and K. K. Kumar, 2018: Estimation of zonally resolved edges of the tropical belt using GPS-RO measurements. IEEE J. Sel. Top. Appl. Earth Obs. Remote Sens., 11, 2555-2561, https://doi.org/10.1109/JSTARS.2018.2828342.

Menzel, M. E., D. Waugh, and K. Grise, 2019: Disconnect between Hadley cell and subtropical jet variability and response to increased $\mathrm{CO}_{2}$. Geophys. Res. Lett., 46, 7045-7053, https:// doi.org/10.1029/2019GL083345.

Miller, R. L., G. A. Schmidt, and D. T. Shindell, 2006: Forced annular variations in the 20th century Intergovernmental Panel on Climate Change Fourth Assessment Report models. J. Geophys. Res., 111, D18101, https://doi.org/10.1029/2005JD006323.

Quan, X.-W., M. P. Hoerling, J. Perlwitz, H. F. Diaz, and T. Xu, 2014: How fast are the tropics expanding? J. Climate, 27, 19992013, https://doi.org/10.1175/JCLI-D-13-00287.1.

Reichler, T., M. Dameris, and R. Sausen, 2003: Determining the tropopause height from gridded data. Geophys. Res. Lett., 30, 2042, https://doi.org/10.1029/2003GL018240.

Saha, S., and Coauthors, 2010: The NCEP Climate Forecast System Reanalysis. Bull. Amer. Meteor. Soc., 91, 1015-1057, https:// doi.org/10.1175/2010BAMS3001.1.

— , and Coauthors, 2014: The NCEP Climate Forecast System version 2. J. Climate, 27, 2185-2208, https://doi.org/10.1175/ JCLI-D-12-00823.1.

Seidel, D. J., and W. J. Randel, 2006: Variability and trends in the global tropopause estimated from radiosonde data. J. Geophys. Res., 111, D21101, https://doi.org/10.1029/2006JD007363.

_, and —, 2007: Recent widening of the tropical belt: Evidence from tropopause observations. J. Geophys. Res., 112, D20113, https://doi.org/10.1029/2007JD008861.

—, Q. Fu, W. J. Randel, and T. J. Reichler, 2008: Widening of the tropical belt in a changing climate. Nat. Geosci., 1, 21-24, https://doi.org/10.1038/ngeo.2007.38.

Simpson, I. R., T. A. Shaw, and R. Seager, 2014: A diagnosis of the seasonally and longitudinally varying midlatitude circulation response to global warming. J. Atmos. Sci., 71, 2489-2515, https://doi.org/10.1175/JAS-D-13-0325.1.

Solomon, A., L. M. Polvani, D. W. Waugh, and S. M. Davis, 2016: Contrasting upper and lower atmospheric metrics of tropical expansion in the Southern Hemisphere. Geophys. Res. Lett., 43, 10 496-10 503, https://doi.org/10.1002/2016GL070917.

Son, S.-W., N. F. Tandon, and L. M. Polvani, 2011: The finescale structure of the global tropopause derived from COSMIC
GPS radio occultation measurements. J. Geophys. Res., 116, D20113, https://doi.org/10.1029/2011JD016030.

Staten, P. W., and T. Reichler, 2008: Use of radio occultation for long-term tropopause studies: Uncertainties, biases, and instabilities. J. Geophys. Res., 113, D00B05, https://doi.org/ 10.1029/2008JD009886.

— and - 2014: On the ratio between shifts in the eddy-driven jet and the Hadley cell edge. Climate Dyn., 42, 1229-1242, https://doi.org/10.1007/s00382-013-1905-7.

—_, J. J. Rutz, T. Reichler, and J. Lu, 2012: Breaking down the tropospheric circulation response by forcing. Climate Dyn., 39, 2361-2375, https://doi.org/10.1007/s00382-0111267-y.

_ T. Teichler, and J. Lu, 2014: The transient circulation response to radiative forcings and sea surface warming. J. Climate, 27, 9323-9336, https://doi.org/10.1175/JCLI-D-14-00035.1.

— J. Lu, K. M. Grise, S. M. Davis, and T. Birner, 2018: Reexamining tropical expansion. Nat. Climate Change, 8, 768775, https://doi.org/10.1038/s41558-018-0246-2.

- - K. M. Grise, S. M. Davis, K. Karnauskas, and N. Davis, 2019: Regional widening of tropical overturning: Forced change, natural variability, and recent trends. J. Geophys. Res. Atmos., 124, 6104-6119, https://doi.org/10.1029/2018JD030100.

Swart, N. C., and J. C. Fyfe, 2012: Observed and simulated changes in the Southern Hemisphere surface westerly windstress. Geophys. Res. Lett., 39, L16711, https://doi.org/ 10.1029/2012GL052810.

Totz, S., S. Petri, J. Lehmann, and D. Coumou, 2018: Regional changes in the mean position and variability of the tropical edge. Geophys. Res. Lett., 45, 12 076-12 084, https://doi.org/ 10.1029/2018GL079911.

Verkhoglyadova, O. P., S. S. Leroy, and C. O. Ao, 2014: Estimation of winds from GPS radio occultations. J. Atmos. Oceanic Technol., 31, 2451-2461, https://doi.org/10.1175/JTECH-D14-00061.1.

Waliser, D. E., Z. Shi, J. R. Lanzante, and A. H. Oort, 1999: The Hadley circulation: Assessing NCEP/NCAR reanalysis and sparse in-situ estimates. Climate Dyn., 15, 719-735, https:// doi.org/10.1007/s003820050312.

Watt-Meyer, O. D., M. W. Frierson, and Q. Fu, 2019: Hemispheric asymmetry of tropical expansion under $\mathrm{CO}_{2}$ forcing. Geophys. Res. Lett., 46, 9231-9240, https://doi.org/10.1029/2019GL083695.

Waugh, D. W., and Coauthors, 2018: Revisiting the relationship among metrics of tropical expansion. J. Climate, 31, 75657581, https://doi.org/10.1175/JCLI-D-18-0108.1.

WMO, 1957: Meteorology-A three-dimensional science. WMO Bull., 6, 134-138.

Xian, T., and C. R. Homeyer, 2019: Global tropopause altitudes in radiosondes and reanalyses. Atmos. Chem. Phys., 19, 56615678, https://doi.org/10.5194/acp-19-5661-2019.

Yin, J. H., 2005: A consistent poleward shift of the storm tracks in simulations of 21 st century climate. Geophys. Res. Lett., 32 , L18701, https://doi.org/10.1029/2005GL023684. 